\title{
THE STUDY OF THE EFFECT OF SUBSTANCE L486-0021 ON THE COURSE OF THE EXPERIMENTAL PULMONARY EDEMA IN RATS
}

\author{
G.L.Litvinenko, L.V.Iakovlieva, S.V.Vlasov, S.M.Kovalenko, V.P.Chernykh
}

National University of Pharmacy

Key words: novel non-steroidal anti-inflammatory drugs; acute inflammation; experimental pulmonary edema; biochemical indices

\begin{abstract}
Development of novel drugs with the anti-inflammatory effect of the chemical origin is an up to date and strategic research area for modern medicinal science. This article represents the results of the experimental anti-inflammatory study of the substance with L486-0021 code using the model of the acute pulmonary edema induced by ammonium chloride toxicosis (the model where exudation dominates). Ammonium chloride irritates the walls of alveoli in the lungs, as the result, the acute hypoxia and acidosis increase permeability of the haemato-pleural barrier and finally results in the alveolar pulmonary edema. The study was performed using Wistar albino female rats weighing 180-200 $\mathrm{g}$. The clinical monitoring included the visual assessment of the state of the animals and their survival value. The effectiveness of therapy was also monitored by biochemical indices (ceruleoplasmin, $C$-reactive protein, interleukin-1 $\beta$ ). The test compound administered in the dose of $10 \mathrm{mg} / \mathrm{kg}$ showed the high anti-edemic effect; it also increased the survival of animals and decreased the values of the main indices of acute inflammation. The level of $C$-reactive protein was decreased by 4 times and interleukin-1 $\beta$ by 2.6 times in relation to the intact control group; as to the value of the therapeutic action substance L486-0021 showed 1.8 times higher effect than the reference drug Xefocam. The substance with L486-0021 code is promising for further study as a potent novel domestic non-steroidal anti-inflammatory drug.
\end{abstract}

Regulation of the inflammaof the main components of different etiology diseases, is an important problem for general pathology and clinical medicine. Nonsteroidal anti-inflammatory drugs (NSAIDs) are widely used for correction of the inflammation. There are about 20 medicinal substances and a great scope of modern non-steroidal anti-inflammatory medicines, however, the problem of highly effective novel anti-inflammatory drugs development is of the great importance.

The main mechanism of action of the most of NSAIDs is inhibition of pro-inflammatory cytokine signals, which stimulate the microvessels of the endothelial tissue in the lungs, stomach, kidney and mucous membranes of the other organs. The numerous information published about the clinical and experimental studies of Xefocam, a drug from Lornoxicam group [14], which has the complex mechanism of action based on prostaglandin suppression as the result of COX isoenzyme inhibition, attracted us to use this substance for our experiments. Its short half-elimination time ( 4 hours regardless of the drug concentration) makes side effects less significant, because during the period between drug administration the renewal of physiological levels of prostaglandins required for protection of the gastric mucosa from the damage takes its place. Xefocam is recommended for treatment of extreme and chronic inflammatory states and associated pathological processes and pain [10].

The previous study showed that substance L486-0021 revealed the typical activity for non-steroidal anti-inflammatory drugs (anti-inflammatory and analgesic activity [7]; moderate alterative and antiproliferative action) and no gastroand hepatotoxicity $[8,9]$. Therefore, it was reasonable to evaluate its effect on the course of the experimental acute pulmonary edema in comparison with the drug Xefocam.

G.L.Litvinenko - teaching assistant of the Department of Clinical Laboratory Diagnostics, external PhD student of the Department of Pharmacoeconomics of the National University of Pharmacy (Kharkiv)

The aim of our work was to study the antiexusudative activity of the most promising substance L486-0021 using the model of the acute pulmonary edema induced by ammonium chloride $\left(\mathrm{NH}_{4} \mathrm{Cl}\right)$ toxicosis.

\section{Materials and Methods}

The model of the acute pulmonary edema induced by abdominal injection of $6 \%$ solution of ammonium chloride $\left(\mathrm{NH}_{4} \mathrm{Cl}\right)$ in the dose of $400 \mathrm{mg}$ per $\mathrm{kg}$ [12] was used.

All experiments were carried out according to the national "General Ethical Principles and Guidelines for Experiments on Animals" (Ukraine, 2001), which are consistent with the provisions of "European Convention for the Protection of Vertebrate Animals used for Experimental and Other Scientific Purposes" (Strasbourg, 1985). The antiexudative activity was estimated using the model of haemato-pleural barrier permeability dysfunction induced by the pulmonary edema of the toxic origin. After experimental abdominal injection of ammonium chloride, the chemical agent is easily absorbed from the peritoneal cavity and further 


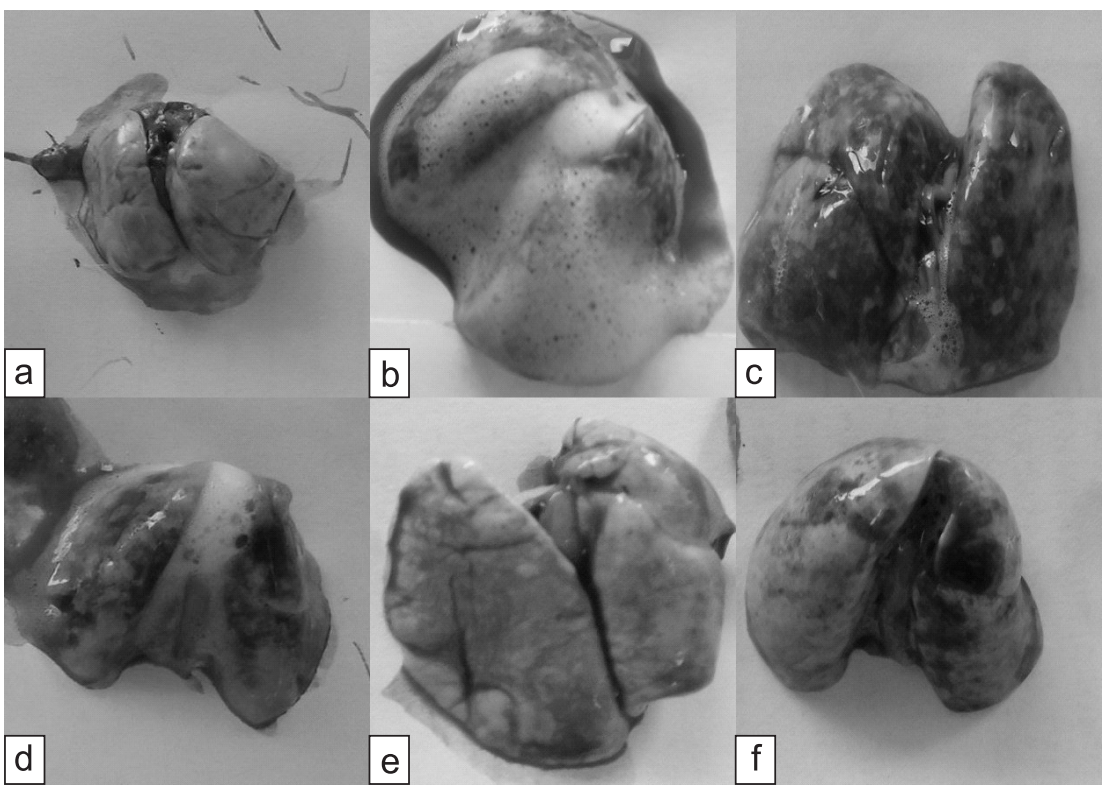

Fig. Acute pulmonary edema induced by ammonium chloride toxicosis: (a) - intact control; (b, c) - positive control; (d) - substance L486-0021 in the dose of dose $1 \mathrm{mg} / \mathrm{kg}$; (e) - substance L486-0021 in the dose of $10 \mathrm{mg} / \mathrm{kg}$; (f) - RD Xefocam in the dose of $3.6 \mathrm{mg} / \mathrm{kg}$ transformed in the liver to urea and hydrochloric acid, which decreases the basicity level of blood and develops acidosis. The distinctive component of this model is the lung hyperammonemia as the Hyperammonemia increases permeability of the haemato-pleural barrier and results in the alveolar pulmonary edema (the model where exudation dominates) [11]. result of $\mathrm{NH}_{4} \mathrm{Cl}$ induced toxicosis.
The study was performed using mature Wistar albino female rats weighing 180-200 g; there were 5 groups of 7 rats in each group: the $1^{\text {st }}$ group was the intact control group (IC); the $2^{\text {nd }}$ group was the positive control group (PC) treated with water in the dose of $1 \mathrm{ml}$ per $100 \mathrm{~g}$ on the background of pathology; substance L486-0021 in the dose of $1 \mathrm{mg}$ per $1 \mathrm{~kg}$ was given to the animals of the $3^{\text {rd }}$ group
Table 1

The antiexudative effect of substance L486-0021 and the reference drug Xefocam in the experimental pulmonary edema model in rats, $n=35, M \pm m$

\begin{tabular}{|l|c|c|c|c|}
\hline Group of animals & $\begin{array}{c}\text { Dose, } \\
\mathrm{mg} / \mathrm{kg}\end{array}$ & $\begin{array}{c}\text { Pulmonary } \\
\text { edema } \\
\text { coefficient }\end{array}$ & $\begin{array}{c}\text { Antiexudative } \\
\text { activity, \% }\end{array}$ & $\begin{array}{c}\text { Animal } \\
\text { survival, \% }\end{array}$ \\
\hline Intact control & - & $0.64 \pm 0.01$ & - & $100 \%$ \\
\hline Positive control & dist. water & $1.30 \pm 0.22^{*}$ & - & $0 \%$ \\
\hline L486-0021 & 1.0 & $1.09 \pm 0.05^{*}$ & $32.1(16 ; 39)^{* * *}$ & $0 \%$ \\
\hline L486-0021 & 10.0 & $0.84 \pm 0.03^{* *}$ & $70.1(59 ; 79)$ & $60 \%$ \\
\hline Xefocam & 3.6 & $1.04 \pm 0.06^{*}$ & $39.7(16 ; 61)^{* * *}$ & $20 \%$ \\
\hline
\end{tabular}

\section{Notes:}

1) $n=7$ - the number of animals in the group;

2) * - statistically significant differences in relation to the intact control, Newman-Keuls test, $\mathrm{p}<0.05$;

3) ** - statistically significant differences in relation to the positive control, Newman-Keuls test, $\mathrm{p}<0.05$;

4) *** - statistically significant differences in relation to substance L486-0021 in the dose of $10 \mathrm{mg} / \mathrm{kg}$, Mann-Whitney test, $\mathrm{p} \leq 0.05$. (the dose was equal to $\mathrm{ED}_{50}$ calculated according to the screening results); the $4^{\text {th }}$ group was treated with substance L486-0021 in the dose of $10 \mathrm{mg}$ per $1 \mathrm{~kg}$ (the maximum effective dose showed high effectiveness for the model of chronic pathology - experimental adjuvant arthritis); the $5^{\text {th }}$ group was treated with the reference drug (RD) Xefocam in the dose of $3.6 \mathrm{mg}$ per $1 \mathrm{~kg}$. The dose of the reference drug was calculated from the human daily dose considering a specific sensitivity factor according to Yu.R.Rybolovlev's method [5]. The substance studied was administrated orally 1 hour before the injection of $\mathrm{NH}_{4} \mathrm{Cl}$. The rats, which remained alive were decapitated after the second hour of the experimental pathology. The values of the antiexudative activity for L486-0021 and RD were estimated by the animals survival and decrease of the pulmonary edema coefficient (PEC). Kruskal-Wallis one-way analysis of variance and Mann-Whitney test were used for statistical analysis of the experimental results obtained [3].

\section{Results and Discussion}

The results of the research of the antiexusudative effect of the substance tested and RD are given in Table 1 and Fig., the biochemical indices of the lung tissue homogenate are presented in Table 2.

The results of the experimental study have shown that the injection of $\mathrm{NH}_{4} \mathrm{Cl}$ to the experimental rats resulted in progression of the acute pulmonary edema. About $60 \%$ of the animals treated with substance L486-0021 in the dose of $10 \mathrm{mg} / \mathrm{kg}$ were in the satisfactory state till the end of the experiment (for 2 hours), and the activity of the drug was up to $70.1 \%$, which appeared to be 1.8 times higher than the effect of the reference drug Xefocam (Table 1). In the rats of all groups thoracic cavities were opened, the lungs were taken out, examined and weighed (Fig.). Substance L486-0021 in the dose of $10 \mathrm{mg} / \mathrm{kg}$ recupera- 


\begin{abstract}
The effect of substance L486-0021 and the reference drug Xefocam on the biochemical indices of the blood serum and lungs homogenate in the experimental acute pulmonary edema model in rats, $n=35, S_{x}$
\end{abstract}

\begin{tabular}{|c|c|c|c|c|c|}
\hline \multirow{2}{*}{ Indices } & \multicolumn{5}{|c|}{ Experimental groups } \\
\hline & Intact control & Positive control & $\begin{array}{c}\text { L486-0021 } \\
1 \mathrm{mg} / \mathrm{kg}\end{array}$ & $\begin{array}{l}\mathrm{L} 486-0021 \\
10 \mathrm{mg} / \mathrm{kg}\end{array}$ & Xefocam \\
\hline \multicolumn{6}{|c|}{ Blood serum } \\
\hline Ceruloplasmin, g/l & $0.092 \pm 0.01$ & $0.163 \pm 0.01^{*}$ & $0.112 \pm 0.01^{* *}$ & $0.109 \pm 0.01^{* *}$ & $0.108 \pm 0.01^{* *}$ \\
\hline $\mathrm{CRP}, \mathrm{mg} / \mathrm{l}$ & $1.92 \pm 0.07$ & $7.14 \pm 0.37^{*}$ & $4.14 \pm 0.23 * / * *$ & $1.8 \pm 0.10^{* *}$ & $3.2 \pm 0.37^{*} / * *$ \\
\hline IL-1 $\beta, \mathrm{pg} / \mathrm{ml}$ & $10.4 \pm 1.09$ & $36.1 \pm 2.93^{*}$ & $27.7 \pm 2.43 * / * *$ & $13.8 \pm 1.67^{* *}$ & $17.4 \pm 1.62 * / * *$ \\
\hline \multicolumn{6}{|c|}{ Lungs homogenate } \\
\hline $\mathrm{RG}, \mu$ mole $/ \mathrm{g}$ & $2.54 \pm 0.12$ & $1.95 \pm 0.06^{*}$ & $1.97 \pm 0.05^{*}$ & $2.12 \pm 0.12^{*}$ & $2.31 \pm 0.15^{* *}$ \\
\hline TBA, $\mu$ mole $/ \mathrm{g}$ & $39.4 \pm 3.8$ & $56.4 \pm 5.2^{*}$ & $45.9 \pm 4.6^{* *}$ & $40.5 \pm 4.2^{* *}$ & $42.3 \pm 2.6^{* *}$ \\
\hline
\end{tabular}

Notes:

1) $n=7$ - the number of animals in the group;

$2)^{*}$ - statistically significant differences in relation to the intact control animals, Newman-Keuls test, $p<0.05$;

$3)^{* *}$ - statistically significant differences in relation to the positive control animals, Newman-Keuls test, $p<0.05$.

ted the state of lungs to the level of IC.

Criteria of acute inflammation development are not only general symptoms of the pathological process (acute respiratory failure), but also the series of biochemical indices. For instance, about 30 blood proteins, which are called the "acute-phase proteins" participate in the progress of the acute inflammatory process. The most important among them are ceruleoplasmin (CP), C-reactive protein (CRP), interleukin-1 $\beta$ (IL-1 $\beta$ ). Ceruleoplasmin is a copper containing $\alpha_{2}$-glycoprotein, which is synthesized by hepatocytes and epitheliocytes of the lungs, it has the antioxidant activity (it is the enzyme ferroxidase), which prevents oxidation of membrane lipids [2]. C-reactive protein is synthesized predominantly in hepatocytes, its concentration in the blood characterizes the severity and the stage of the pathological process [13]. Interleukin- $1 \beta$ is a multifunctional cytokine, which regulates inflammatory and immune processes, activates neutrophils, T- and B-lymphocytes, stimulates the synthesis of acute-phase proteins and prostaglandins [6].

The research results showed that in the blood serum of the ani- mals of the control pathology group the statically significant increase of the concentration all of the inflammation markers in relation to IC was observed. The treatment of animals with substance L4860021 in the dose of $10 \mathrm{mg} / \mathrm{kg}$ for CRP decreased the concentration of CRP and IL-1 $\beta$ (by 4 and 2.6 times, respectively) comparatively with the level for the intact control group. It indicates the higher effectiveness of this dose compared to the dose of $1.0 \mathrm{mg} / \mathrm{kg}$. The influence of the RD Xefocam considerably decreased the values of all of the similar markers in relation to the group of the control pathology: CP by 1.5 times, CRP by 2.2 times and Il- $1 \beta$ by 2.1 times; but the effect of RD appeared to be less than the effect of substance L486-0021 in the dose of $10 \mathrm{mg} / \mathrm{kg}$ by 1.2 for IL-1 $\beta$ and by 1.7 times.

The few sources reported about the role of lipid peroxidation during the pulmonary edema propose contradictory information; most of the authors consider initiation of lipid peroxidation and the antioxidant system failure as one of the most important mechanism of edema progression in lungs, the others think that inhibition of lipid peroxidation in the lungs in the ede- matous factors action may contribute the increase of the pulmonary edema [1].

The data obtained evidently indicates that in the course of the acute pulmonary edema the evidences of lipid peroxidation progress were statistically obvious although their level was low: the concentration of TBA reactive products in the lung tissue grew by 1.4 comparatively with the values of the IC group animals. The progress of the pathological process was accompanied with decrease of the reduced glutathione (RG) level in the lung tissue by 1.3 times. It is reported [4] that the lung tissue is highly stable against accumulation of the lipid peroxidation products in hypoxia. It has been also confirmed in our experiments by relatively low values of $R G$ and TBA-reactive products in the lung tissue in the alveolar pulmonary edema in rats.

\section{CONCLUSIONS}

1. The results of the research have shown that substance L4860021 in the dose of $10 \mathrm{mg} / \mathrm{kg}$ on the model of the acute pulmonary edema induced by ammonium chloride toxicosis exhibited the antiexsudative activity up to $70.1 \%$, recuperated the state of the lungs almost to the IC level exceeding 
the effect of the reference drug Xefocam.

2. The treatment of animals with substance L486-0021 in the dose of $10 \mathrm{mg} / \mathrm{kg}$ evidently decreased the level of CRP by 4 times and IL- $1 \beta$ by 2.6 times comparatively with the level for the intact control group; as to the value of the therapeutic action substance L4860021 showed 1.8 times higher effect than the reference drug Xefocam.

3. It has been found that in the course of the acute toxic pulmonary edema substance L486-0021 in the dose of $10 \mathrm{mg} / \mathrm{kg}$ and the reference drug Xefocam decrease the concentration of lipid peroxidation products to the IC level, and it confirms the membrane stabilizing action of this substance.

4. The substance with L4860021 code is promising for further study as a potent novel domestic non-steroidal anti-inflammatory drug.

\section{REFERENCES}

1. Бурбелло А.Т., Шабров А.В., Денисенко П.П. Современные лекарственные средства: Клинико-фармакологический справочник практического врача. - С.Пб.: Нева; М.: Олма-Пресс, 2002. - 799 с.

2. Ким Л.Б., Калмыкова Е.Ю. // Клин. лабораторная диагностика. - 2006. - №5. - С. 13-18.

3. Лапач С.Н., Чубенко А.В., Бабич П.Н. Статистические методы в медико-биологических исследованиях с использованием Excel. - К.: Морион, 2001. - 408 с.

4. Могильницкая Л.В., Фан А., Баранова Н.Ю., Шугалей В.С. // Бюл. эксперим. биол. и медицины. 1992. - №5. - C. 497-498.

5. Рыболовлев Ю.Р., Рыболовлев Р.С. // Доклады АН СССР - 1979. - Т. 247, №6. - С. 1513-1516.

6. Симбирцев А.С., Пигарева Н.В., Конусова В.Г. // Вестник РАМН. - 1993. - №2. - С. 18-22.

7. Яковлєва Л.В., Литвиненко Г.Л., Шаповал О.М., Федосов А.І. // Медицина И... . - 2009. - №1 (23). C. 78-83.

8. Яковлєва Л.В., Литвиненко Г.Л. // Клінічна фармація. - 2010. - Т. 14, №1. - С. 55-57.

9. Яковлєва Л.В., Литвиненко Г.Л., Лар'яновська Ю.Б. // Клінічна фармація, фармакотерапія та медична стандартизація. - 2011. - №3-4. - С. 71-76.

10. Akcali G.E., Iskender A., Demiraran Y. et al. // J. Endourol. - 2010, Apr. - 24 (4). - P. 615-620.

11. Ammonia (Environmental Health Criteria 54). - Geneva: World Health Organization, 1986. - 210 p.

12. Gibaldi M. Biopharmaceutics and clinical pharmacokinetics. - Philadelphia: Lea \& Febiger, 1991.

13. Monteiro C.M. // Braz. J. Med. Biol. Res. - 2010. - Vol. 43, №3. - P. 297-302.

14. Prasad Byrav D.S., Medhi B., Prakash A. et al. // I. J. PMR. - 2009. - Vol. 20 (1). - P. 27-31.

ВИВЧЕННЯ ВПЛИВУ РЕЧОВИНИ L486-0021 НА ПЕРЕБІГ ЕКСПЕРИМЕНТАЛЬНОГО НАБРЯКУ ЛЕГЕНІВ У ЩУРІВ

Г.Л.Литвиненко, Л.В.Яковлєва, С.В.Власов, С.М.Коваленко, В.П.Черних

Національний фармацевтичний університет

Ключові слова: нові нестероїдні протизапальні речовини; гостре запалення; експериментальний набряк легенів; біохімічні показники

Пошук нових препаратів серед субстанцій хімічного походження з протизапальним ефектом є актуальним і одним 3 пріоритетних напрямків сучасної медицини. Представлені матеріали експериментального вивчення протизапальної дії речовини під шифром L486-0021 на моделі гострого токсичного альвеолярного набряку легенів у щурів в умовах інтоксикації амонієм хлориду (модель із перевагою ексудації). В легенях амонію хлорид подразнює мембрани альвеол, внаслідок чого розвивається виражена гіпоксія і ацидоз, які, у свою чергу, збільшують проникність гематоплеврального бар'єру, що в кінцевому результаті призводить до розвитку альвеолярного набряку легенів. Дослідження проводили на самиях шурів лінії Wistar з масою тіла 180-200 г. Клінічні спостереження включали візуальну оцінку стану тварин та їх виживаність. 3 метою оцінки ефективності лікування було проведено дослідження ряду біохімічних по-

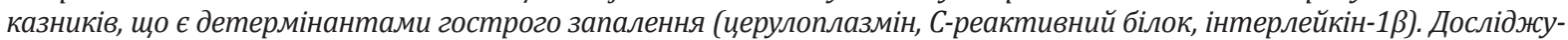
вана речовина під шифром L486-0021 у дозі 10 мг/кг проявила виразну протинабрякову дію, сприяла виживанню тварин та зниженню рівня основних показників гострого запалення: С-реактивного білка у 4 рази та інтерлейкіну-1 $\beta-y$ 2,6 рази відносно тварин інтактного контролю та за виразністю цієї дії суттєво перевищила препарат порівняння «Ксефокам» у 1,8 рази. Речовина під шифром L486-0021 є перспективною для подальшого вивчення з метою створення нового вітчизняного нестероїдного протизапального препарату.

\section{ИЗУЧЕНИЕ ВЛИЯНИЯ ВЕЩЕСТВА L486-0021 НА ТЕЧЕНИЕ ЭКСПЕРИМЕНТАЛЬНОГО ОТЕКА ЛЕГКИХ У КРЫС}

\section{А.Л.Литвиненко, Л.В.Яковлева, С.В.Власов, С.Н.Коваленко, В.П.Черных}

\section{Национальный фармацевтический университет}

Ключевые слова: новые нестероидные противовоспалительные вещества; острое воспаление; экспериментальный отек легких; биохимические показатели

Поиск новых препаратов среди субстанций химического происхождения с противовоспалительным эффектом является актуальным и одним из приоритетных направлений современной медицины. Представлены мате- 
риалы экспериментального изучения противовоспалительного действия вещества под шифром L486-0021 на модели острого токсического альвеолярного отека легких у крыс в условиях интоксикации аммонием хлорида (модель с преимуществом экссудации). В легких аммония хлорид раздражает мембраны альвеол, вследствие чего развивается выраженная гипоксия и ацидоз, которые, в свою очередь, увеличивают проницаемость гематоплеврального барьера, что в конечном итоге приводит к развитию альвеолярного отека легких. Исследования проводили на крысах самцах линии Wistar с массой тела 180-200 г. Клинические наблюдения включали визуальную оценку состояния животных и их выживаемость. С целью оценки эффективности лечения был проведен ряд биохимических показателей (церулоплазмин, C-реактивный белок, интерлейкин-1ß). Исследуемое вещество под шифром L486-0021 в дозе 10 мг/кг проявляло выраженное антиэкссудативное действие, способствовало выживанию животных и снижению уровня основных показателей острого воспаления: С-реактивного белка в 4 раза и интерлейкина-1 - в 2,6 раза относительно животных интактного контроля и по выраженности этого действия существенно превзошло препарат сравнения «Ксефокам» в 1,8 раза. Вещество под шифром L486-0021 является перспективным для дальнейшего изучения с целью создания нового отечественного нестероидного противовоспалительного препарата.

Address for correspondence:

Received in 17.09.2014

53, Pushkinska str., Kharkiv, 61002, Ukraine.

Tel. (57) 706-23-46. E-mail: moxova.79@mail.ru; cndlnfau@mail.ru.

National University of Pharmacy 